\title{
REVIEW 5 JURNAL DOSEN PENDIDIKAN IPS
}

\author{
Oleh : \\ Ainun Cahya \\ email: aiinun1680@gmail.com
}

Pendidikan IPS

Universitas Lambung Mangkurat

REVIEW JURNAL DOSEN IPS

1. LAPORAN AKHIR PENGABDIAN KEPADA MASYARAKAT PROGRAM HABITUASI PENDIDIKAN KARAKTER MELALUI BACA TULIS AL-QUR'AN PADA ANAK USIA DINI DI DESA CANOCO, KECAMATAN ANJIR MUARA, BARITO KUALA

2. LAPORAN PENGABDIAN KEPADA MASYARAKAT KEGIATAN PELATIHAN KARYA TULIS ILMIAH BIDANG ILMU SOSIAL DI MAN 2 MODEL BANJARMASIN

3. LAPORAN PENELITIAN KEHIDUPAN SOSIAL DAN EKONOMI MASYARAKAT BANTARAN SUNGAI SEBAGAI SUMBER BELAJAR IPS (Studi Kasus di Kelurahan Sungai Jingah Kota Banjaramasin)

4. Technological, Pedagogical, Content Knowledge (TPACK): A Discursions in Learning Innovation on Social Studies

5. 21st-Century Skills and Social Studies Education 


\section{LAPORAN AKHIR PENGABDIAN KEPADA MASYARAKAT PROGRAM HABITUASI PENDIDIKAN KARAKTER MELALUI BACA TULIS AL- QUR'AN PADA ANAK USIA DINI DI DESA CANOCO, KECAMATAN ANJIR MUARA, BARITO KUALA \\ Disusun Oleh:}

Ketua: Dr. Bambang Subiyakto, M.Hum (0009025606)

Anggota:

M. Rezky Noor Handy, M.Pd.

Aulia Riska Nugraheny (181012822002)

M. Hadi Nur (1810128110011)

Dona Ekalovianie (1810128320004)

\section{Simpulan dan Hasil Review}

Degradasi moral ditandai oleh karakter negatif yang dimiliki oleh remaja yakni perilaku bullying, tawuran, plagiat, hingga pornografi. Diperlukan muatan karakter dalam praktik pendidikan sehingga remaja mendapatkan filtrasi terhadap karakter negatif. Pendidikan karakter adalah bentuk kegiatan yang di dalamnya terdapat tindakan yang mendidik diperuntukkan bagi generasi selanjutnya. Pendidikan karakter bertujuan untuk membentuk diri individu secara terusmenerus dan melatih kemampuan diri demi menuju kearah hidup yang lebih baik dan optimal. Ruang kelas di sekolah adalah salah satu media belajar yang bisa dimanfaatkan untuk pendidikan karakter.

Terdapat beberapa nilai-nilai dalam pendidikan karakter, Pendidikan karakter dapat diartikan sebagai pendidikan yang memberikan nilai-nilai, budi pekerti, moral, ataupun pendidikan yang membentuk watak. Menyadari kondisi karakter masyarakat saat ini, pendidikan karakter menjadi program nasional sejak satu dasawarsa terakhir. Pemerintah berinisiatif untuk mengutamakan penerapan karakter bangsa dalam pendidikan. Hal ini diwujudkan dalam rencana pembangunan jangka panjang nasional tahun 2005-2025 yang menyatakan bahwasannya pendidikan karakter adalah bagian dari visi misi bangsa dalam mewujudkan pembangunan 
nasional yang disebut dengan 3 gerakan nasional pendidikan karakter, sehingga Penguatan Pendidikan Karakter (PPK) adalah lanjutan dari Gerakan Nasional Pendidikan Karakter (GNPK).

Tujuan dan makna dari pendidikan karakter sama halnya dengan pendidikan moral dan pendidikan akhlak, karena dalam pendidikan karakter ini lebih mendominasi tentang akhlak (Sahlan dkk, 2017). Konsep pendidikan karakter ini bertujuan untuk menjadikan seseorang atau membentuk seseorang menjadi manusia yang baik secara kecerdasan intelektual (IQ), kecerdasan spiritual (SQ), kecerdasan emosional (EQ), maupun kecerdasan memahami segala kesulitan (AQ). Oleh karena itu, dalam konteks pendidikan di Indonesia tidak lepas dari pendidikan nilai.

Pendidikan karakter melalui pengajaran baca tulis Al-Qur'an diharapkan diamalkan dalam kehidupan sehari-hari dan menjadi manusia yang seutuhnya (insan kamil) yang memiliki akhlak yang mulia (akhlakul karimah). Ada pula yang mendefinisikan pendidikan sebagai proses dimana sebuah bangsa mempersiapkan generasi mudanya untuk menjalankan kehidupan, dan untuk memenuhi tujuan hidup secara efektif dan efisien.

Esensi pendidikan secara umum, maka yang perlu diketahui selanjutnya adalah hakikat karakter sehingga bisa ditemukan pengertian pendidikan karakter secara komprehensif. Istilah karakter digunakan secara khusus dalam konteks pendidikan baru muncul pada akhir abad 18, terminologi karakter mengacu pada pendekatan idealis spiritualis yang juga yang juga dikenal dengan teori pendidikan normatif, dimana yang menjadi prioritas adalah nilai-nilai transenden yang dipercaya sebagai motivator dan dominisator sejarah baik bagi individu maupun bagi perubahan nasional.

Hasil review saya mengenai "LAPORAN AKHIR PENGABDIAN KEPADA MASYARAKAT PROGRAM HABITUASI PENDIDIKAN KARAKTER MELALUI BACA TULIS AL-QUR'AN PADA ANAK USIA DINI DI DESA CANOCO, KECAMATAN ANJIR MUARA, BARITO KUALA" ini sangat bagus dan bermanfaat sekali baik itu bagi pembaca maupun yang terlibat dalam pembuatan artikel tersebut kegiatan yang dilakukan dosen tersebut khususnya dose-dosen IPS yang meneliti tentang pendidikan karakter tersebut memberi wawasan dan ilmu baru bagi pembaca, karena sesuatu yang baru ditemukan atau diteliti telah memberi jendela baru bagi pembacanya.

\section{LAPORAN PENGABDIAN KEPADA MASYARAKAT}




\section{KEGIATAN PELATIHAN KARYA TULIS ILMIAH BIDANG ILMU SOSIAL DI \\ MAN 2 MODEL BANJARMASIN \\ Disusun Oleh:}

Ketua: Mutiani,S.Pd., M.Pd. (0007098902)

Anggota:

Mahmudah Hasanah, M.Pd. (0021037903)

M. Rezky Nor Handy, M.Pd.

M. Faisal (1610128110005)

Rusli (1610128210017)

Hendry Alfiani Arisandi (1810128220010)

\section{Simpulan dan Hasil Review}

Penulisan karya ilmiah memiliki beberapa tujuan. Secara umum, penulisan karya ilmiah memiliki tujuan melatih seseorang untuk menyusun hasil pemikiran dan hasil penyelidikannya menurut cara-cara yang lazim untuk membuat penjelasan dan data dikemukakan yang dikemukakan dalam laporan ilmiah. Dalam konteks yang lebih khusus, karya ilmiah memiliki tujuan melaporkan keterangan dan pikiran secara jelas, ringkas dan tegas.

Karya tulis ilmiah mengusung permasalahan keilmuan. Materi yang dalam tulisan ilmiah berupa gagasan-gagasan ilmiah, baik berupa hasil kajian ilmiah maupun hasil-hasil penelitian yang disajikan dalam karya tulis ilmiah. Dengan kata lain, karya tulis ilmiah merupakan karangan yang menyajikan fakta umum yang dapat dibuktikan kebenarannya secara ilmiah dan ditulis dengan metodologi yang tepat. Karya tulis yang logis berarti karya tulis yang memiliki data, argument, dan penalaran ilmiah yang bisa diterima oleh logika. Rendahnya kualitas karya ilmiah ini disebabkan oleh minimnya penguasaan pengetahuan, metodologi penelitian, hingga kondisi emosional yang tidak stabil.

Di sisi lain, dan rendahnya penguasaan keterampilan menulis ilmiah juga menjadi polemik klasik dalam penulisan. Pelatihan penulisan karya ilmiah yang dikembangkan di sekolah memiliki beberapa manfaat bagi peserta didik, sebagai: (1) manfaat bagi peserta didik: (a) Membangkitkan rasa keingintahuan fenomena alam yang berhubungan dengan ilmu pengetahuan dan teknologi, (b) meningkatkan kemampuan berpikir terhadap fenomena alam, (c) meningkatkan kreativitas yang menumbuhkan kemampuan berkreasi dan daya kritis, (d) Menambah wawasan mengenai ilmu pengetahuan dan teknologi, (e) meningkatkan keterampilan 
menguasai ilmu pengetahuan dan teknologi, (f) meningkatkan minat membaca tentang hal-hal yang berkaitandengan pengetahuan dan teknologi,(g) Memperluas wawasan dan kemampuan komunikasi melalui pengalaman diskusi, debat, dan presentasi ilmiah, (h) Memperkenalkan caracara berorganisasi secara formal, (i) Sebagai wahana untuk menempa sikap kedewasaan dan kepribadian, (j) Mengenal sifat -sifat ilmiah, jujur, optimis, terbuka, percaya diri, toleransi, kreatif, kritis, dan skeptis, (k) Sebagai ajang uji coba prestasi dan prestise, (l) Membuka kesempatan untuk mendapat prioritas melanjutkan jenjang pendidikan yang lebih tinggi dan berkualitas. (k) Sebagai ajang uji coba prestasi dan prestise, (l) Membuka kesempatan untuk mendapat prioritas melanjutkan jenjang pendidikan yang lebih tinggi dan berkualitas. (k) Sebagai ajang uji coba prestasi dan prestise, (l) Membuka kesempatan untuk mendapat prioritas melanjutkan jenjang pendidikan yang lebih tinggi dan berkualitas.

Hasil Review saya mengenai artikel hasil penelitian tersebut adalah lebih kepengajaran tentang membuat suatu karya tulis ilmiah yang diselenggarakan di sekolah menengah atas, artikel ini tidak saja berfungsi untuk mahasiswa tetapi untuk umum membuat para pembaca yang ingin belajar atau mencari sesuatu tentang karya tulis dapat saja membaca hasil penelitian ini.

\section{LAPORAN PENELITIAN}

KEHIDUPAN SOSIAL DAN EKONOMI MASYARAKAT BANTARAN SUNGAI SEBAGAI SUMBER BELAJAR IPS (Studi Kasus di Kelurahan Sungai Jingah Kota

\section{Banjaramasin)}

\section{Tim Peneliti:}

Ketua:

Dr. Herry Porda N.P., M.Pd.

Anggota:

Jumriani, M.Pd.

Dhicky Darmawan

Sri Nuryatin

\section{Simpulan dan Hasil Review}

Kehidupan Sosial Masyarakat Bantaran Sungai di Kelurahan Sungai Jingah Kota Banjarmasin. Kelurahan Sungai Jingah merupakan salah satu Kelurahan di Banjarmasin yang masyarakatanya bermukim di bantaran sungai, Kehidupan masyarakat yang bermukim di 
bantaran sungai Kelurahan Sungai Jingah sangat berorientasi pada sungai, sebelum adanya akses jalan darat, baik dari aspek sosial maupun ekonomi masyarakat.

Seiring dengan perkembangan zaman, terjadi pergeseran pemanfaatan sungai pada beberapa aspek bagi kehidupan sosial dan ekonomi masyarakat. Kehidupan sosial dan ekonomi masyarakat bantaran sungai menjadi perhatian untuk diteliti karena berfungsi strategis bagi pembelajaran Ilmu Pengetahuan Sosial (IPS), khususnya sebagai sumber belajar. Penelitian ini bertujuan untuk; Mendeskripsikan kehidupan sosial masyarakat bantaran sungai di Kelurahan Sungai Jingah Kota Banjarmasin. Penelitian ini menggunakan pendekatan kualitatif. Pengumpulan data dilakukan melalui wawancara, observasi dan dokumentasi. Teknik analisis data dilakukan dengan melakukan reduksi data, penyajian data dan penarikan kesimpulan. Pengujian keabsahan data dilakukan dengan perpanjangan pengamatan, meningkatkan ketekunan, member check, dan triangulasi. Hasil penelitian menunjukkan bahwa kehidupan sosial masyarakat di Bantaran Sungai Kelurahan Sungai Jingah erat dengan nuansa kekeluargaan, Begitupulan dengan budaya banjar masih dipertahakan pada kehidupan masyarakat.

Hasil Review saya tentang hasil penelitian tersebut adalah sangat bermanfaat dan membantu para mahasiswa dalam mengenal lebih dalam budaya-budaya yang ada di suku banjar atau kebiasaan-kebiasaan yang dilakukan oleh suku banjar. Tidak hanya bermanfaat bagi para mahasiswa khususnya pendidikan ips tetapi juga pada jurusan lain yang berkaitan tentang kebudayaan, ekonomi, politik dan bahkan diluar jurusan pun bisa membaca dan berguna karena ini akan menambah pengetahuan baru bagi pembaca karena penelitian ini membahas kebiasaankebiasaan yang dilakukan oleh masyarakat banjar.

\author{
Technological, Pedagogical, Content Knowledge (TPACK): A Discursions in Learning \\ Innovation on Social Studies \\ Disusun Oleh: \\ Mutiani \\ mutiani@upi.edu \\ Nana Supriatna \\ nanasup@yahoo.com \\ Ersis Warmansyah Abbas
}


ersiswa@ulm.ac.id

Tika Puspita Widya Rini

tika.rini@ulm.ac.id

Bambang Subiyakto

bambangsb@ulm.ac.id

\section{Simpulan dan Hasil Review \\ Mutiani, Nana Supriatna, Ersis Warmansyah Abbas, Tika Puspita Widya Rini, \& Bambang Subiyakto}

Ada tujuh domain pengetahuan di TPACK, yaitu: 1) pengetahuan pedagogis, 2) pengetahuan konten, 3) pengetahuan teknologi, 4) konten pedagogis pengetahuan, 5) pengetahuan konten teknologi, 6) pengetahuan pedagogis teknologi, dan 7) pengetahuan konten pedagogis teknologi (Loughran et al., 2012; Mishra et al., 2011). Dalam aspek ini, guru IPS dapat memahami pelajaran yang akan diajarkan, meliputi pengetahuan tentang fakta, konsep, teori, dan prosedur dalam bidang tertentu, pengetahuan kerangka yang dapat mengorganisasikan dan menghubungkan ide dan pengetahuan tentang aturan, dan bukti isinya. Guru IPS dapat memanfaatkan beberapa teknologi yang mendukung pembelajaran IPS yaitu: laptop dan proyektor (LCD) untuk menampilkan video dalam pembelajaran. Pengetahuan PCK termasuk dalam memilih pendekatan atau metode pembelajaran apa untuk memilih untuk mengajarkan konten tertentu.

Pertama, pengetahuan pedagogis (PK) dipahami sebagai pengetahuan tentang hakikat mengajar dan pembelajaran, termasuk metode pengajaran, pengelolaan kelas, perencanaan pembelajaran, penilaian pembelajaran siswa (Anderson et al., 2013). Hal ini tentunya berkaitan dengan proses, strategi, prosedur atau langkah-langkah, dan metode belajar mengajar. Pada aspek pertama, PK diharapkan meningkatkan kemampuan guru IPS khususnya dalam meramu pembelajaran berdasarkan kebutuhan dari siswa. Pembelajaran IPS yang mengedepankan prinsip-prinsip esensial yang terintegrasi. Dengan demikian, sosial belajar belajar menjadi kuat.

Kedua, Content Knowledge (CK) adalah pengetahuan yang berkaitan dengan materi pelajaran yang diajarkan (misalnya matematika, bahasa, sosial, seni, dan sebagainya) (Baran \& Uygun, 2016). Dalam aspek ini, guru IPS dapat memahami pelajaran yang akan diajarkan, termasuk pengetahuan tentang fakta, konsep, teori, dan prosedur dalam bidang tertentu, 
pengetahuan tentang kerangka kerja yang dapat mengorganisasikan dan menghubungkan ide dan pengetahuan tentang aturan, dan bukti konten. Dalam praktiknya, studi sosial guru dapat menghubungkan keterkaitan ilmu sosial dalam materi tertentu seperti Manusia, Tempat, dan, Lingkungan di kelas VII semester 1.

Ketiga, pengetahuan teknologi (TK) adalah keberlanjutan dan pengembangan berbasis pengetahuan, termasuk pengetahuan tentang teknologi (Harris \& Hofer, 2011; Kereluik et al., 2011). Ini pengetahuan digunakan untuk memproses informasi, berkomunikasi, memecahkan masalah, fokus pada produktif aplikasi yang terintegrasi ke dalam pembelajaran IPS. Guru IPS dapat memanfaatkan beberapa teknologi yang mendukung pembelajaran IPS yaitu: laptop dan proyektor (LCD) untuk menampilkan video dalam pembelajaran. Selain itu, guru dapat menggunakan alat web quizizz untuk membuat pertanyaan terkait untuk mata pelajaran IPS siswa.

Keempat, Pedagogical Content Knowledge (PCK) adalah pengetahuan tentang pedagogi, pengajaran praktek, dan proses perencanaan yang berlaku dan sesuai untuk diajarkan pada materi pelajaran yang diberikan (Loughran et al., 2012). Pengetahuan PCK termasuk dalam memilih pendekatan atau metode pembelajaran apa untuk memilih untuk mengajarkan konten tertentu. Pilihan pendekatan atau metode dalam mengajar matematika berbeda dengan pendekatan atau metode pengajaran bidang lain seperti bahasa Indonesia, IPA, atau Ilmu Sosial. PCK berkaitan dengan representasi dan perumusan konsep, pedagogis teknik, pengetahuan tentang apa yang membuat suatu konsep sulit atau mudah dipelajari, dan juga pengetahuan tentang pengetahuan dari teori epistemologis peserta didik sebelumnya (Koehler \& Mishra, 2008).

Dalam aspek ini, guru IPS dapat memahami pelajaran yang akan diajarkan, termasuk pengetahuan tentang fakta, konsep, teori, dan prosedur dalam bidang tertentu, pengetahuan tentang kerangka kerja yang dapat mengatur dan menghubungkan ide dan pengetahuan tentang aturan, dan bukti. dari konten. Guru IPS dapat memanfaatkan beberapa teknologi yang mendukung pembelajaran IPS, yaitu: laptop dan proyektor (LCD) untuk menampilkan video dalam pembelajaran.

Kelima, technology content knowledge (TCK) adalah pengetahuan tentang hubungan antara subjek dan teknologi Contohnya mengaitkan materi dengan teknologi yang berkembang saat ini, seperti guru IPS menguraikan materi IPS terkait perubahan sosial dengan kebutuhan 
teknologi masyarakat. Dalam TCK, guru harus fasih dalam memilih bahan ajar dan mengaitkannya dengan perkembang an teknologi.

Keenam, pengetahuan pedagogis teknologi (TPK) adalah pengetahuan tentang pengaruh teknologi pada proses belajar mengajar dan kelebihan dan kendala teknologi terkait dengan desain dan strategi pedagogis (Niess, 2011; Pamuk et al., 2015). Keberadaan TPK bagi guru IPS dapat menunjang pembelajaran IPS yang mencerminkan kebutuhan perkembangan teknologi. TPACK mengintegrasikan teknologi yang kompleks dalam pembelajaran dengan memperhatikan tiga aspek yaitu pedagogi, konten, dan teknologi itu sendiri dalam pembelajaran yang dikembangkan oleh guru secara efektif.

Pembelajaran IPS adalah untuk memberikan ruang inovasi agar pembelajaran IPS menjadi menyenangkan. Guru IPS dapat mendalami materi dalam pembelajaran IPS dengan menampilkan contoh-contoh konkrit (disajikan di layar) sehingga mudah dipahami. Keberadaan TPACK dalam pembelajaran IPS dimaknai sebagai inovasi untuk menggerakkan partisipasi siswa dengan memanfaatkan teknologi dan Guru dapat mengembangkan materi yang sebenarnya.

Hasil Review saya mengenai jurnal di atas adalah sangat membantu dalam mencari informasi bagi pemula atau bagi mahasiswa yang membutuhkan informasi seperti ini khususnya jurusan pendidikan Ips. Akan tetapi, kekurangan jurnal tersebut bagi pembaca khususnya bagi mahasiswa baru ataupun mahasiswa yang tidak mengerti bahasa inggris karena jurnal tersebut menggunakan bahasa Inggris.

\title{
21st-Century Skills and Social Studies Education
}

Disusun Oleh :

\author{
Aslamiah \\ aslamiyah640@gmail.com \\ Ersis Warmansyah Abbas \\ ersiswa@ulm.ac.id \\ Mutiani \\ mutiani@ulm.ac.id
}

\section{Simpulan dan Hasil Review}




\section{Aslamiah, Ersis Warmansyah Abbas, \& Mutiani}

Pengetahuan dan wawasan kepada peserta didik tentang konsep dasar ilmu sosial dan humaniora, memiliki kepekaan dan kesadaran terhadap masalah sosial di lingkungan, serta memiliki keterampilan mempelajari dan memecahkan masalah. Peningkatan kualitas manusia untuk bertahan dan beradaptasi dengan era global dapat dikembangkan dalam pendidikan IPS. Keterkaitan pendidikan IPS dan abad 21 dipelajari oleh Arif Widodo dkk tahun 2020 dengan judul "Pendidikan IPS Menanggapi Tantangan Abad 21: Kritik Terhadap Praktik Pembelajaran IPS di Sekolah Dasar" Hasil penelitian menggambarkan bahwa globalisasi dan kemajuan teknologi mengubah tatanan sosial dan budaya manusia (Widodo et al. al., 2020). Siswa harus siap beradaptasi dengan situasi baru yang membutuhkan keterampilan baru kedua, Belajar untuk melakukan. Belajar untuk melakukan atau belajar untuk hidup, berorientasi pada keterampilan pemecahan masalah berpikir kritis keterampilan pada tataran praktis dapat menganalisis suatu masalah dari berbagai sudut pandang untuk mendapatkan solusi yang bijak terhadap masalah berdasarkan pemikiran logis.

Keterampilan berpikir kritis termasuk mampu membedakan kebenaran dari kebohongan, fakta, atau opini. Membuat keputusan dengan pemikiran yang masuk akal dan reflektif membutuhkan pemikiran kritis keterampilan untuk memutuskan apa yang harus dipercaya dan dilakukan. Berpikir kritis bermanfaat karena manusia dapat berpikir realistis dengan alasan yang logis dan rasional untuk memecahkan suatu. Kreativitas berkaitan dengan beberapa keterampilan lain seperti berpikir kritis dan membuat keputusan serta memecahkan masalah, komunikasi, dan kolaborasi (Mahanal, 2014). Keterampilan abad 21 dapat dikembangkan melalui mata pelajaran IPS. Sementara, pembelajaran IPS di tingkat SMP menggunakan pendekatan terpadu, yang menggabungkan beberapa konsep disiplin ilmu sosial seperti sejarah, geografi, sosiologi, dan

ekonomi (Abbas, 2013). Keterkaitan sosial pendidikan IPS dengan pengembangan keterampilan abad 21 dapat termuat dalam IPS Tujuan Pendidikan dalam kurikulum 2006.

Pendidikan IPS to bertujuan untuk memastikan bahwa siswa memiliki kemampuan berikut: mengenali konsep yang terkait related dengan kehidupan masyarakat, dan memiliki keterampilan yang diperlukan untuk berpikir logis dan kritis, rasa ingin tahu, penyelidikan, pemecahan masalah, dan keterampilan dalam kehidupan sosial; memiliki komitmen dan kesadaran dalam dirinya terhadap nilai-nilai sosial dan kemanusiaan; dan mampu berkomunikasi, 
bekerja sama, dan bersaing dalam masyarakat yang majemuk, baik di tingkat lokal, nasional, maupun global (Somantri et al., 2001).

Hasil Review saya mengenai jurnal di atas adalah sangat membantu dalam mencari informasi bagi pemula atau bagi mahasiswa yang membutuhkan informasi seperti ini khususnya jurusan pendidikan Ips. Akan tetapi, kekurangan jurnal tersebut bagi pembaca khususnya bagi mahasiswa baru ataupun mahasiswa yang tidak mengerti bahasa inggris karena jurnal tersebut menggunakan bahasa Inggris.

\section{Referensi}

Aslamiah, A., Abbas, E. W., \& Mutiani, M. (2021). 21st-Century Skills and Social Studies Education. The Innovation of Social Studies Journal, 2(2), 82-92.

Mutiani, M., Supriatna, N., Abbas, E. W., Rini, T. P. W., \& Subiyakto, B. (2021). Technological, Pedagogical, Content Knowledge (TPACK): A Discursions in Learning Innovation on Social Studies. The Innovation of Social Studies Journal, 2(2), 135-142.

Mutiani, M. (2020). Pengabdian Kepada Masyarakat Kegiatan Pelatihan Karya Tulis Ilmiah Bidang Ilmu Sosial di MAN 2 Model Banjarmasin.

Putro, H. P. N., \& Jumriani, J. (2020). KEHIDUPAN SOSIAL DAN EKONOMI MASYARAKAT BANTARAN SUNGAI A SEBAGAI SUMBER BELAJAR IPS.

Subiyakto, B. (2020). Laporan Akhir Pengabdian Kepada Masyarakat Program Habituasi Pendidikan Karakter Melalui Baca Tulis Al-Qur'an Pada Anak Usia Dini Di Desa Canoco, Kecamatan Anjir Muara, Barito Kuala. 